\title{
The landmark Escazú Agreement: An opportunity to integrate democracy, human rights, and transboundary conservation
}

\author{
Sofía López-Cubillos $^{1,2,3}$ (1) ｜ Lina Muñoz-Ávila ${ }^{4}$ (i) ｜ Leslie A. Roberson ${ }^{1,2}$ (i) | \\ Andrés F. Suárez-Castro ${ }^{2,5}$ (D) | Jose Manuel Ochoa-Quintero ${ }^{5}$ (i) | \\ Renato Crouzeilles $^{6,7,8}$ (i) ｜ Eduardo Gallo-Cajiao9 (D) ｜ Jonathan Rhodes ${ }^{1,2}$ (i) | \\ Wolfram Dressler $^{10}$ (1) ｜ María José Martinez-Harms ${ }^{11,12}$ (i) $\quad$ Rebecca K. Runting $^{10}$ (i) \\ ${ }^{1}$ School of Earth and Environmental Science, University of Queensland, St. Lucia, Queensland, Australia \\ ${ }^{2}$ Centre for Biodiversity and Conservation Science, University of Queensland, St. Lucia, Queensland, Australia \\ ${ }^{3}$ Fundación Manigua desde la Tierra, Bogotá, Colombia \\ ${ }^{4}$ Facultad de Jurisprudencia, Universidad del Rosario, Bogotá, Colombia \\ ${ }^{5}$ Instituto de Investigación de Recursos Biológicos Alexander von Humboldt, Bogotá, Colombia \\ ${ }^{6}$ International Institute for Sustainability, Rio de Janeiro, Brazil \\ ${ }^{7}$ International Institute for Sustainability Australia, Australian Capital Territory, Canberra, Australia \\ ${ }^{8}$ Mestrado Profissional em Ciências do Meio Ambiente, Veiga de Almeida University, Rio de Janeiro, Brazil \\ ${ }^{9}$ School of Marine and Environmental Affairs, University of Washington, Seattle, Washington, USA \\ ${ }^{10}$ School of Geography, Earth and Atmospheric Sciences, University of Melbourne, Parkville, Victoria, Australia \\ ${ }^{11}$ Instituto Milenio en Socio Ecología Costera, Pontificia Universidad Católica de Chile, Santiago, Chile \\ ${ }^{12}$ Instituto de Ecología y Biodiversidad, Santiago, Chile
}

\section{Correspondence}

Sofía López-Cubillos, School of Earth and Environmental Science, University of Queensland, 2/54 Redfern St., Wool-

loongabba, QLD 4101, Australia.

Email: d.lopezcubillos@uq.edu.au

\begin{abstract}
Latin America and the Caribbean (LAC) is one of the world's most biodiverse regions, but this diversity is threatened by the overexploitation of natural resources and internal social conflicts. In 2018, 33 LAC countries were invited to sign and ratify the landmark Escazú Agreement, which is the first legally binding environmental agreement to explicitly integrate human rights with environmental matters. The agreement outlines an approach to enhance the protection of environmental defenders, increase public participation in environmental decision-making, and foster cooperation among countries for biodiversity conservation. However, clear mechanisms to implement the ideals of the Agreement are currently lacking. We identify the key provisions of the Agreement and link these to tangible mechanisms which aim to integrate human rights and nature conservation. These mechanisms include technological (e.g., free online data),
\end{abstract}


human-based (e.g., legal advice from multidisciplinary teams), and nature-based solutions (e.g., transboundary species management). As environmental assets-and threats to them--span national boundaries, the collaborative and participatory provisions of the agreement could catalyze coordinated transboundary environmental management. Because of the importance of this Agreement for the LAC region, we added a Spanish version of this manuscript in the Supplementary Material (versión del artículo en español en el material suplementario).

\section{KEYWORDS}

access to information, big data, capacity building, cooperation, environmental defenders, environmental legislation, NGOs, stakeholders

\section{1 | INTRODUCTION}

Latin America and the Caribbean's (LAC) globally important biodiversity is under threat from multiple anthropogenic activities, such as habitat change and pollution (Rodríguez Garavito \& Baquero Díaz, 2020), and human rights violations are hindering the capacity of social movements to protect the environment (Butt et al., 2019). These threats are rarely restricted to single countries, as many ecosystems are shared across political borders (e.g., Rodríguez-Jorquera et al., 2017; Anderson et al., 2018). Weak governance and lack of collaboration among jurisdictions has allowed these threats to escalate (Coumans, 2019). The LAC region thus faces major challenges for coordinated biodiversity management, including capacity building of social actors to effect change. A recently developed international agreement, the Escazú Agreement, represents a critical juncture as it can provide key tools to coordinate environmental management in the region.

In 2012, 10 LAC countries gathered in Rio+20 to endorse a declaration--the Escazú Agreement--that applies the three main pillars of Principle 10 of the Rio Declaration (Stec \& Jendrośka, 2019): 1. Information, 2. Participation, and 3. Justice. This is the first legally binding international agreement that aims to guarantee human rights through an effective implementation of environmental democracy by fostering information generation and access to it. In addition, it advocates for social and environmental justice by encouraging the participation of all stakeholders, especially local and indigenous communities, in environmental decision-making. Further, the Agreement looks to strengthen cooperation among LAC countries, and mandate the protection of environmental defenders (CEPAL, 2018). Subsequently, 33 LAC countries were invited to sign the Escazú Agreement before September 2020 (CEPAL, 2018). The agreement entered into force on the International Earth Day after it was ratified by 12 signatory coun- tries. To date, 11 additional signatory countries have signed it but not yet ratified (Table S1).

The Escazú Agreement does not set conservation targets, but instead provides guidance on environmental democracy, cooperation, and human rights, which is intended to be adaptable to each country's context (Article 4.3, Stec and Jendrośka (2019)). It is, therefore, crucial that there is clarity around the mechanisms that could facilitate the integration of the Agreement's articles for advancing biodiversity conservation and the protection of the environmental defenders. Here, we propose three broad mechanisms to achieve this goal (i.e., technological, humanbased, and nature-based) and identify key initiatives that exemplify opportunities to implement the Agreement provisions (i.e., legal statements within the Agreement, Figure 1). We also detail how these provisions have enormous potential to facilitate transboundary conservation across the region.

\section{2 | OPPORTUNITIES BASED ON THE AGREEMENT PROVISIONS}

We identified the provisions, and associated articles that contribute most tangibly to nature conservation and human rights; we grouped them into three main themes: 1. Democracy, 2. Human rights, and 3. Enabling processes (Table 1). For each theme, we identified key mechanisms and associated initiatives that have been implemented at national or subnational scales in specific countries from LAC (e.g., legal rights of nature in the Ecuadorian constitution). These initiatives have the potential to be scaledup into larger projects and/or replicated in other LAC countries. Some mechanisms can bolster the implementation of more than one provision; for instance, the use of technology can increase the generation of environmental information-and access to it (theme 1, Table 1), while also enhancing capacity building (theme 3 , Table 1 ). Together, 


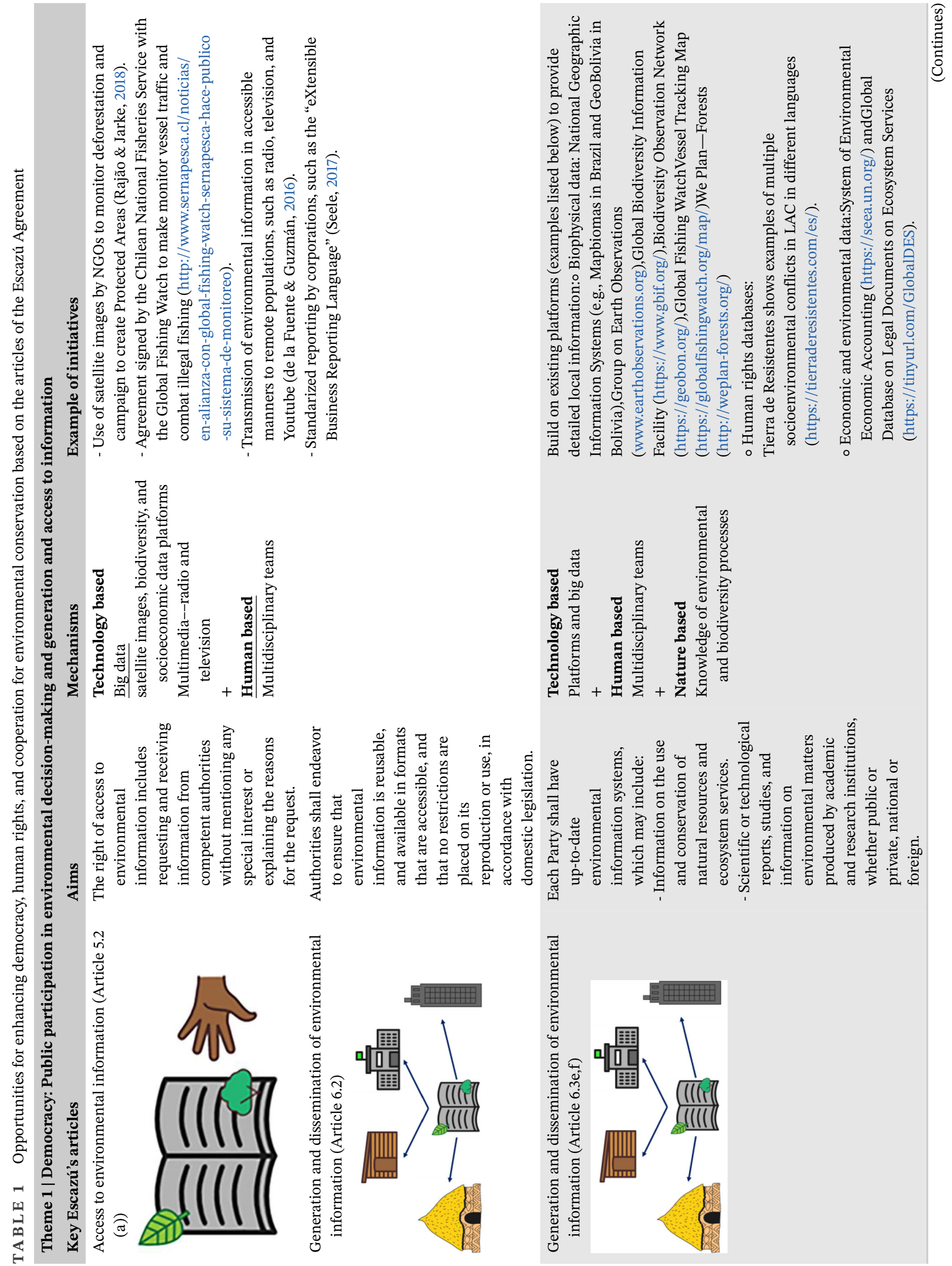




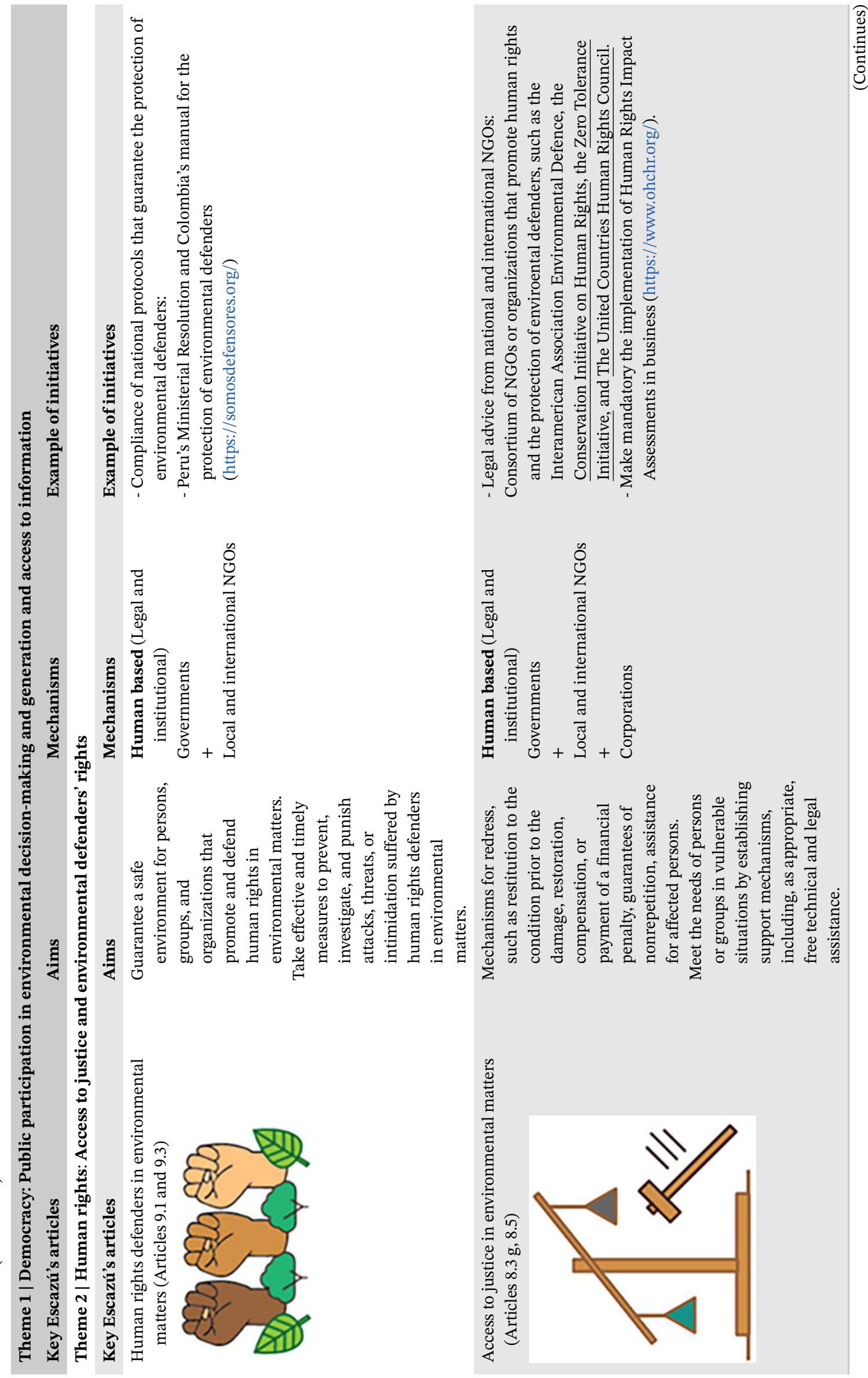




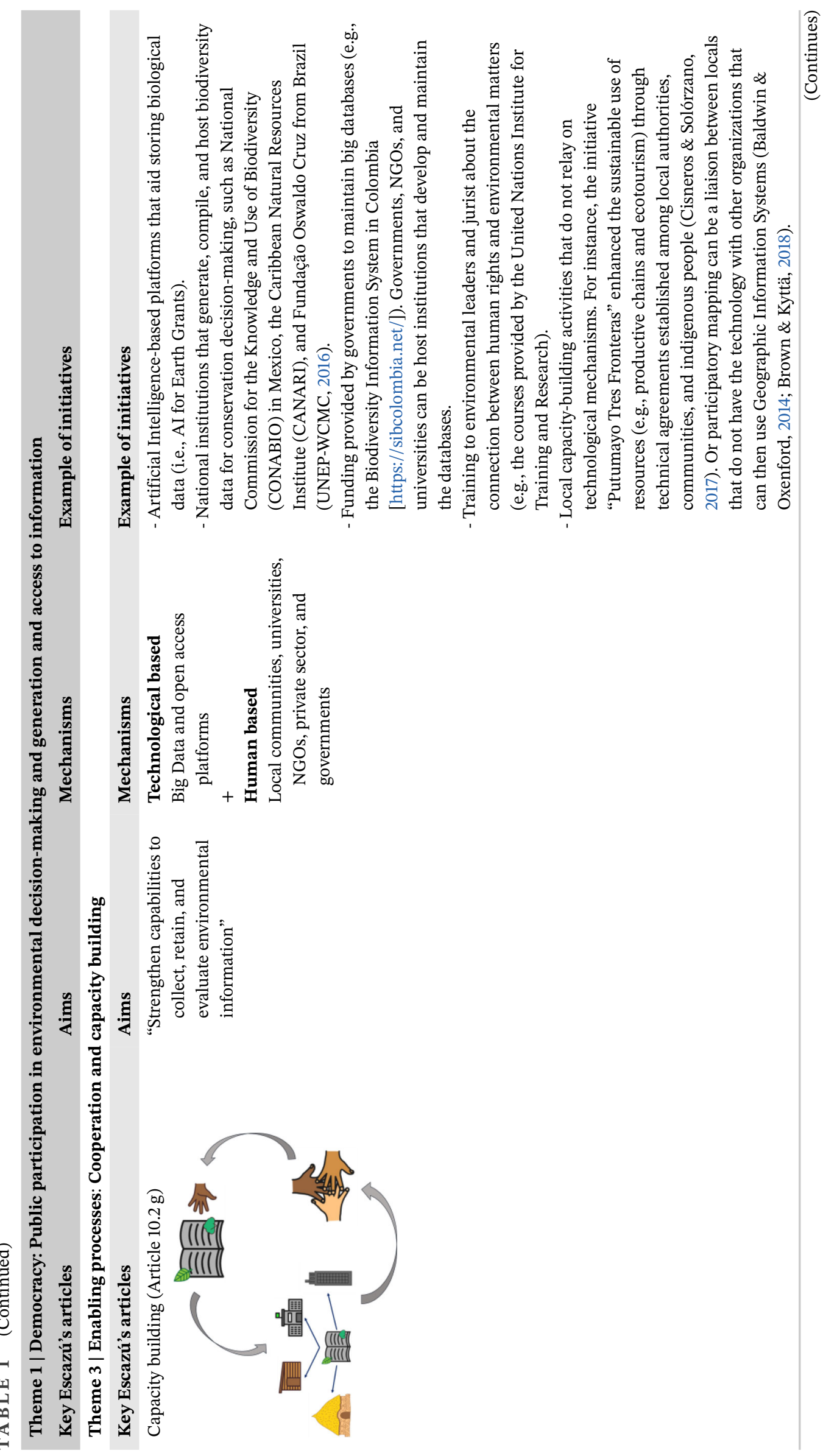




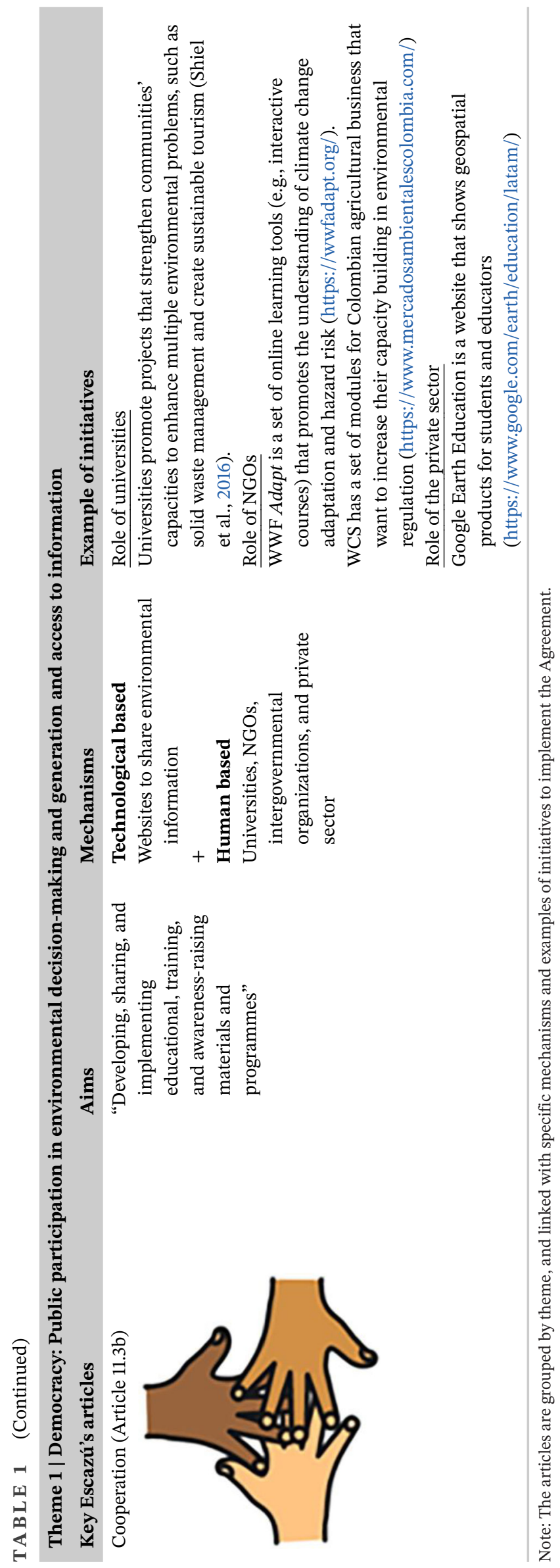




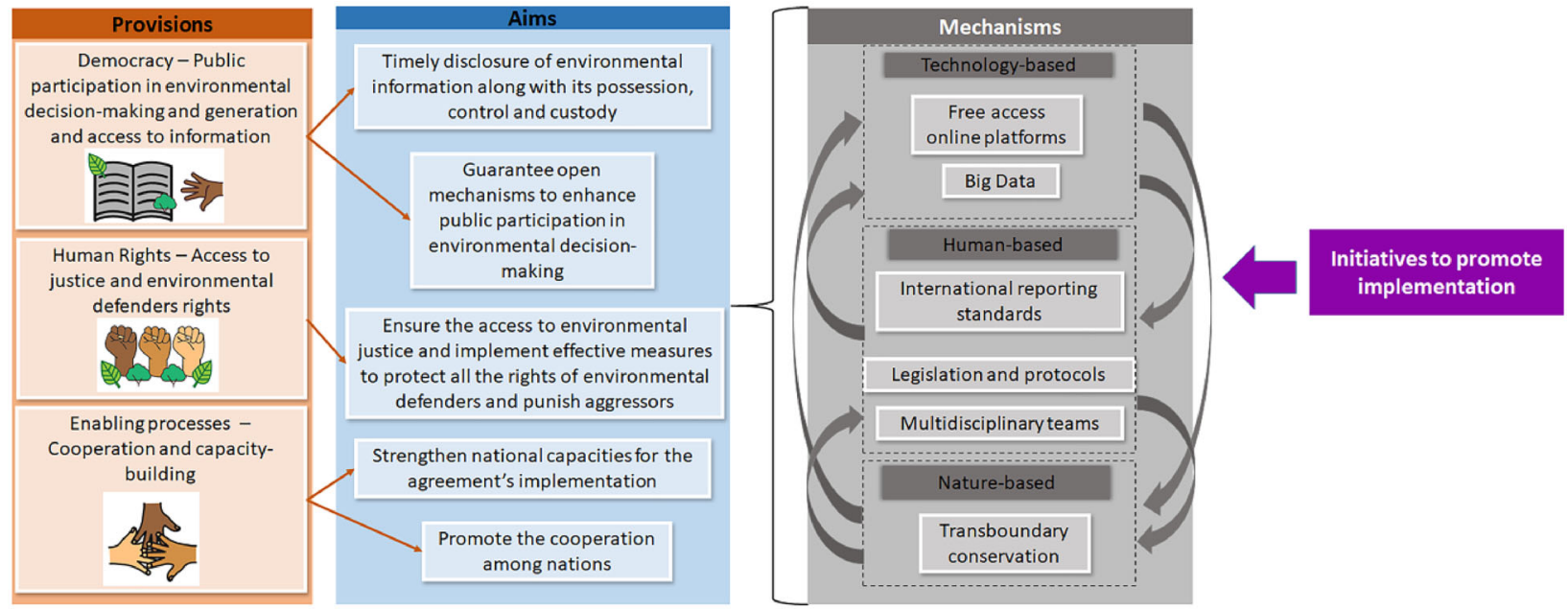

F I G U R E 1 Diagram showing the connection between key provisions, their aims, and the Escazú Agreement implementation

these mechanisms and initiatives provide guidance for how the Agreement aims can be achieved.

\section{1 | Theme 1: Democracy--Public participation in environmental decision-making and generation and access to information}

Increasing public participation in environmental management requires the generation of environmental information as well as making existing information easily available (Oksanen \& Kumpula, 2013). Thus, information sharing, including the reduction of information asymmetries, is a key binding provision in the Agreement (Articles 5-7, CEPAL, 2018). Public participation is essential for improved environmental outcomes by increasing the quality of knowledge provided by local experts, enhancing public awareness, and enabling the implementation of environmental plans (Armitage et al., 2012). Unfortunately, many environmental decisions in the LAC region lack transparency and the accessibility of information is not guaranteed, which makes timely public participation in environmental matters very difficult.

Despite the challenges, participatory democracy can be fostered using technological and human-based mechanisms (Table 1). Recent progress in collecting, processing, and summarizing large volumes of data ("big data") surrounding many environmental issues is not just generating information, but is also improving the accessibility of this information (Runting et al., 2020). For instance, spatial data on deforestation in the Brazilian Amazon was previously restricted to government agencies (in the 1970s), but methodological advancements mean NGOs can now track deforestation over time using open source data (Rajão \& Jarke, 2018). The initial shift to public data was only pos- sible after pressure from social movements (i.e., grassroots and NGOs), and this combination of big data, transparency, and public participation has led to the creation of new protected areas in the region (Rajão \& Jarke, 2018). However, many stakeholders, like rural communities, may not have access to big data resources. Therefore, additional tools are required to ensure all stakeholders have access to environmental information to help achieve the transparency needed for public participation.

Radio and television can enhance access to environmental information by communicating to wider audiences. For instance, the impacts of a mega-tourism project in the National Park Cabo Pulmo (Mexico) were reported on one of the main television channels (de la Fuente \& Guzmán, 2016). Furthermore, there is a demand from isolated rural communities for information about environmental matters from the media streams they can access (Vásquez \& Santafé, 2021). Critically, substantial funds will be needed to support both big data and the use of multimedia (e.g., TV and radio) to disseminate environmental information. It is also paramount that the potential of big data to increase transparency is pursued alongside meaningful stakeholder engagement, based on a bottomup approach to set questions, in order to achieve the ultimate aim of public participation in environmental management. This transparency in environmental decisionmaking is also essential to ensure protection for environmental defenders.

\section{2 | Theme 2: Human rights--Access to justice and environmental defender rights}

Individuals and groups of environmental activists, also known as "environmental defenders", are important for the governance and protection of the environment (Butt 
et al., 2019). ${ }^{1}$ Sustained levels of harassment, intimidation, and murder arise when defender actions against extractive activities become entangled in the associated political and economic alliances of powerful state actors, paramilitary entities, and corporations (Tierra de Resistentes, 2021 and see Box 1 as an example). Alarmingly, Central and South America had almost half of the global total deaths of environmental defenders in 2019 (Global Witness, 2020), and Indigenous people, particularly those from Colombia, have suffered the most globally between 2015 and 2017 (Butt et al., 2019). The loss of environmental defenders' lives reverberates throughout communities and can lead to declines in social capital due to the loss of key leaders and ongoing intimidation. This could have further negative repercussions on the wellbeing of environmental defenders' communities, as irresponsible economic development activities continue to impact their surroundings. A call has already been raised for a binding policy instrument that regulates and monitors both national and international owners of mining companies in Brazil, following the collapse of a mining dam that killed 20 people and degraded several thousands of square kilometers of indigenous lands (Garcia et al., 2017). Although there are some international treaties and declarations that promote human rights (e.g., Universal Declaration of Human Rights), the Escazú Agreement is an answer to such a call, as it is the first legally binding instrument targeting the protection of environmental defenders and their human rights to live in a safe environment (Stec \& Jendrośka, 2019). The Escazú Agreement can actually serve as a reference for the InterAmerican Court of Human Rights' jurisprudence, as has been done with similar conventions (e.g., Aarhus Convention in EU, Stec \& Jendrośka, 2019). However, Article 9 of the Agreement (Table 1) will be difficult to achieve, and will require sustained cooperation and transparency from governments, business, and NGOs (Prieur et al., 2020).

To be effective, the Agreement must align with national enforcement laws, political will, and local mechanisms aimed to protect environmental rights of local communities. Different LAC countries have established some mechanisms that aim to protect environmental defenders (Table 1) and these need to be scaled-up and applied more broadly across the region. For instance, Peru designed a protocol within a Ministerial Resolution to investigate social threats and provide defenders with legal assistance in 2019 (see https://www.gob.pe/institucion/minam/noticias/508236-

\footnotetext{
${ }^{1}$ The UN uses the broader term "environmental human rights defenders" (EHRD) to refer to "individuals and groups who, in their personal or professional capacity and in a peaceful manner, strive to protect and promote human rights relating to the environment, including water, air, land, flora and fauna" UNE (2018).
}

aprueban-protocolo-sectorial-para-la-proteccion-dedefensores-ambientales). National and international legal support plays a key role in the protection of environmental defenders, with NGOs being important actors. In March 2021, for example, Amazon indigenous communities from Brazil and Colombia, with the support of an international environmental NGO, sued a French supermarket chain, arguing that this institution sold beef products that promoted deforestation and threatened indigenous lives (https://www.france24.com/en/live-news/20210303amazon-indigenous-groups-sue-casino-chain-overdeforestation). Further, reporting on the environmental impacts of supply chains could be extended to include human rights impacts. The Agreement specifies the importance of considering international obligations in the legal system for the adequate protection of human rights (Article 9). Therefore, the adoption of the International Human Right Standards along national laws that protect civil liberties would allow consumers and companies to more easily monitor their impacts on human rights (OHCHR, 2011).

The depth of injustice perpetrated against environmental defenders means overcoming such violence will be a difficult, but necessary, path. It should be a governmental priority to protect environmental defenders from further violence, but current national and international protocols and frameworks have failed to achieve this. The ratification of the Escazú Agreement will not on its own ensure the protection of environmental defenders if there is no political will or enforcement. However, it offers a base for LAC countries undergoing political changes in favor of supporting environmental defenders.

\section{3 | Theme 3: Enabling processes--Cooperation and capacity building}

Urgent issues, such as improving democracy and environmental justice, require solutions through dialogue and cooperation among multiple stakeholders. Cooperation in the LAC region could help addressing issues of uneven technical and financial capacity across countries and allow for the diffusion of mechanisms for implementation (Hileman et al., 2018). For instance, initiatives developed in one country can provide blueprints to strengthen institutions or legal frameworks in others. Similarly, cooperation could allow the scaling up of initiatives by reducing costs and aggregating data through centralization. Since Rio+20, LAC countries have promoted regional and international initiatives that incorporate the value of solidarity and mutual support as the best way to achieve sustainable development and environmental protection. To 
BOX 1. Environmental defenders threatened as they fight for biodiversity conservation in Colombia

\section{A. How nature benefits from environmental defenders actions in Colombian}

Social movements and environmental defenders have played an important role in safeguarding biodiversity in Colombia, particularly in regions with weak state presence. For instance, the Yelloweared Parrot (Ognorhynchus icterotis) improved from Critically Endangered to Vulnerable, thanks to habitat restoration efforts led by environmental leaders, such as Gonzalo Cardona and many others (Salaman et al., 2019). Gonzalo Cardona was recently murdered, and while the motives of this crime are still under investigation, the Yelloweared Parrot has lost a champion. Additionally, Francia Márquez organized afro-women from the Pacific region to fight against illegal gold mining (that was a significant driver of deforestation) for which she received the Goldman Prize (goldmanprize.org/recipient/francia-marquez/).

Yellow-eared Parrot (Ognorhynchus icterotis) (Author: Francesco Veronesi)

\section{B. Threats and impunity}

Environmental defenders in Colombia face serious danger due to illegal exploitation of natural resources, guerrillas' armed conflict, and corruption in infrastructure contracts. Francia Márquez survived an attack in 2019 and Francisco Vera, an 11-year-old environmental campaigner, received death threats. Since 2016, 302 attacks on environmental defenders were registered but only about $15 \%$ are under investigation and $1 \%$ have resulted in sentencing, demonstrating the lack of legal prosecution and high impunity (U.N., 2020).

\section{Escazú potential for the protection of envi- ronmental defenders}

Ratification of the Agreement would increase the participation of environmental defenders in designing policies and regulations that address the threats they face. This Agreement could also strengthen the capacities of judicial and investigative authorities to fight against impunity.

achieve effective cooperation in the Escazú Agreement (Articles 1 and 11), key social actors, such as local communities, academics, NGOs, private sector, and local governments, should be involved in the design and implementation of cooperative actions (i.e., human-based mech- anisms, Table 1). For instance, the coastal management capacity in Belize's marine protected areas (MPAs) was enhanced with meetings where a variety of stakeholders (local NGOs, community workers, and government fisheries officers) created an action plan to improve management, education, support, and policy development for MPAs (Crabbe et al., 2009). In addition, technological solutions could increase countries' capacity to collect, retain, and evaluate environmental information (as stated in Article 10.2 g). Participatory mapping using Geographic Information System (GIS) can advance social goals through the collection and communication of spatial information from a broad range of stakeholders, such as indigenous and rural communities (Brown \& Kyttä, 2018).

While cooperation is essential to increase implementation within and among countries, numerous challenges remain. Asymmetrical power relations can halt cooperation, as some stakeholders or types of expertise can be seen as more legitimate than others (Fidelman et al., 2014). It is, therefore, essential to address power imbalances and recognize the value of different knowledge systems. Additionally, technical and financial difficulties can hinder capacity building in many countries from the global south (Runting et al., 2020). Here, international donors can play an important role in facilitating large-scale conservation initiatives, such as the international funding provided to the Amazon Fund governance program in Brazil (Marcovitch \& Pinsky, 2014). International or pooled funds could also be used to centralize large databases through online openaccess facilities shared among different countries (Costello et al., 2014).

\section{3 | POTENTIAL OF ESCAZÚ AGREEMENT TO ENHANCE TRANSBOUNDARY CONSERVATION}

Conserving transboundary species and ecosystems will not only require effective cooperation but it will also depend on transparency, participation, and strong legal frameworks. Identifying common objectives among countries--such as the conservation of species that span national borders-is a key element for successful cooperation. In terms of biological diversity, the LAC region has at least 241,050 terrestrial and 9310 marine species that have transboundary ranges (Figure 2a, Supplementary Material). For terrestrial species, a large number of species are found in South America particularly among Peru, Brazil, Colombia, Ecuador, Guyana, and Venezuela (Figure 2a, dark red and dark orange). For marine species, Central America and the Caribbean harbor the most transboundary marine species in the region, with Mexico, Panama, Nicaragua, Costa Rica, and Colombia sharing most of the species (Figure 2a, 


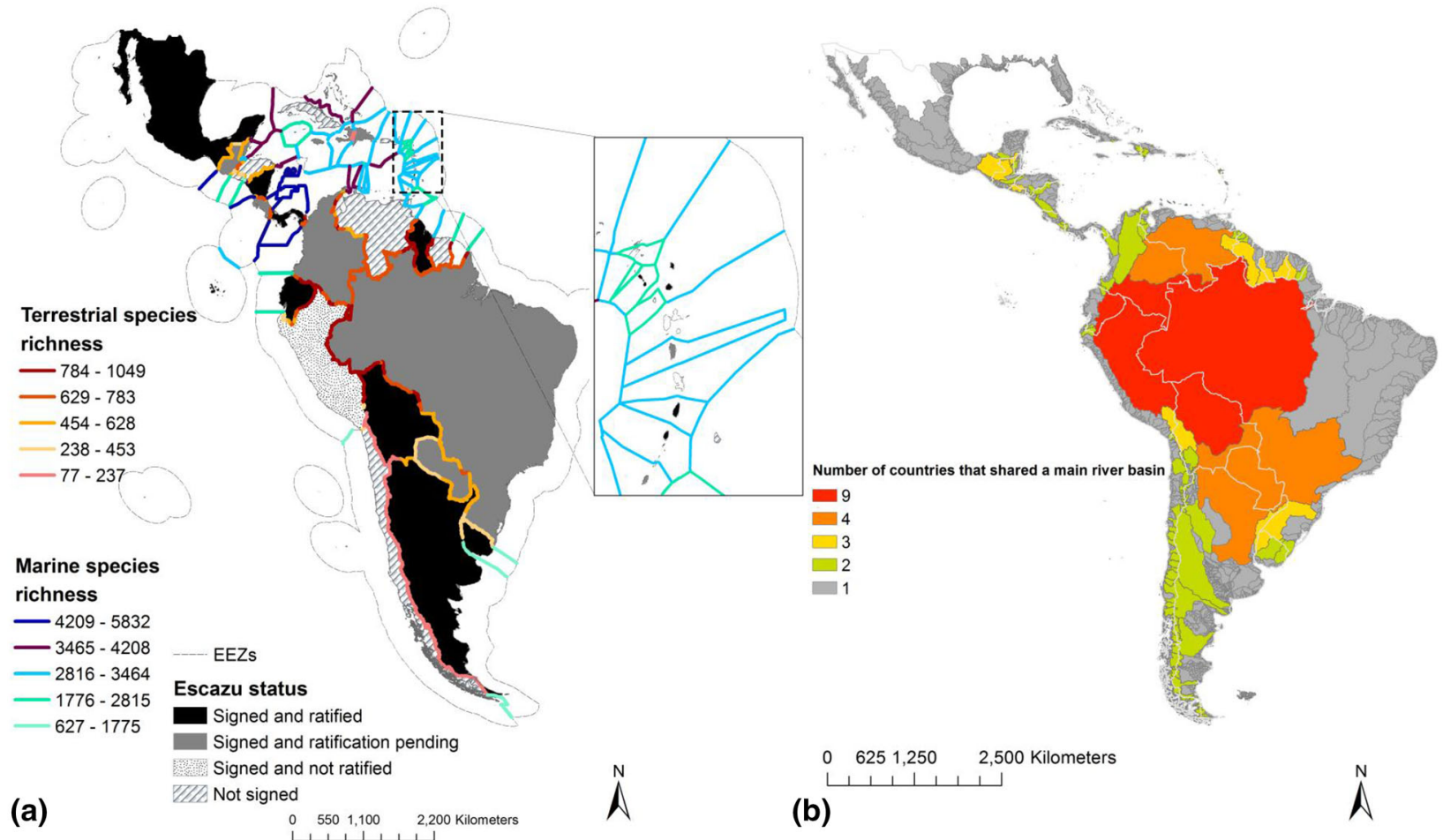

F I G U R E 2 Terrestrial (mammals, birds, and amphibians, red gradient) and marine (marine and semimarine animals, except amphibians, blue gradient) species richness with transboundary ranges across each border and Escazú status. (b) River basins according to the number of countries they span. Abbreviation: EEZ, exclusive economic zone

dark blue and purple). However, this pattern of diversity is not yet closely aligned with countries' membership to the Agreement. Several island countries that are not signatories (e.g., Cuba and Bahamas) share over 3000 transboundary marine species across their Exclusive Economic Zones (Figure 2a). Furthermore, the LAC region contains numerous major river basins spanning two or more countries (Figure 2b, Supplementary Material). Notably, the Amazon basin is shared by nine countries from which only two have ratified (Figure 2b). Even worse, the Orinoco basin is almost equally shared by Colombia (pending ratification) and Venezuela (not signed, Figure 2b).

In addition to species and ecosystems, the LAC region has a biocultural diversity that is at risk of extinction (Amano et al., 2014). Unfortunately, cultural and linguistic diversity has often been overlooked as an important part of biodiversity conservation (Frainer et al., 2020). Yet, lands under indigenous tenure or managed by indigenous communities overlap with $40 \%$ of protected areas and ecologically intact landscapes worldwide (Garnett et al., 2018), which highlights the importance of the protection of these cultures for both human rights and biodiversity conservation. Such complex and diverse environments of the LAC region will inevitably require cooperative management between national governments and indigenous peoples. A promising example can be seen in Chile's "Marine and Coastal Areas for Indigenous Peoples" policy (law 20249) to incentivize marine conservation and recognize the customary rights of indigenous people over marine ecosystems (Hiriart-Bertrand et al., 2020). It is essential that biocultural conservation that addresses the loss of both biological and cultural diversity of the LAC region is incorporated in transboundary management.

The shared species and river basins in the LAC region highlight the urgent need (and opportunities) to create transboundary commitments to protect biodiversity and natural resources. While coordinated transboundary conservation among countries has been promoted in international conventions (e.g., Bonn Convention and Leticia Pact), mechanisms to facilitate implementation are still required (Mason et al., 2020; Prist et al., 2019). The Escazú Agreement's provisions in relation to information sharing, environmental justice, and capacity building could provide a solid platform to support current and future institutional arrangements for transboundary conservation efforts (Figure 3). For instance, creating and sharing a transboundary terrestrial and marine GIS database among countries can enhance the dissemination and use of environmental information (Articles 6.2 and 11.1, see appendix for articles' description). Balwin and Oxenford (2014) created a participatory mapping approach for the Grenadine Islands and St. Vincent and the Grenadines, which allowed the production of maps to accommodate the needs of the marine resource managers (e.g., enhanced resolution of marine 


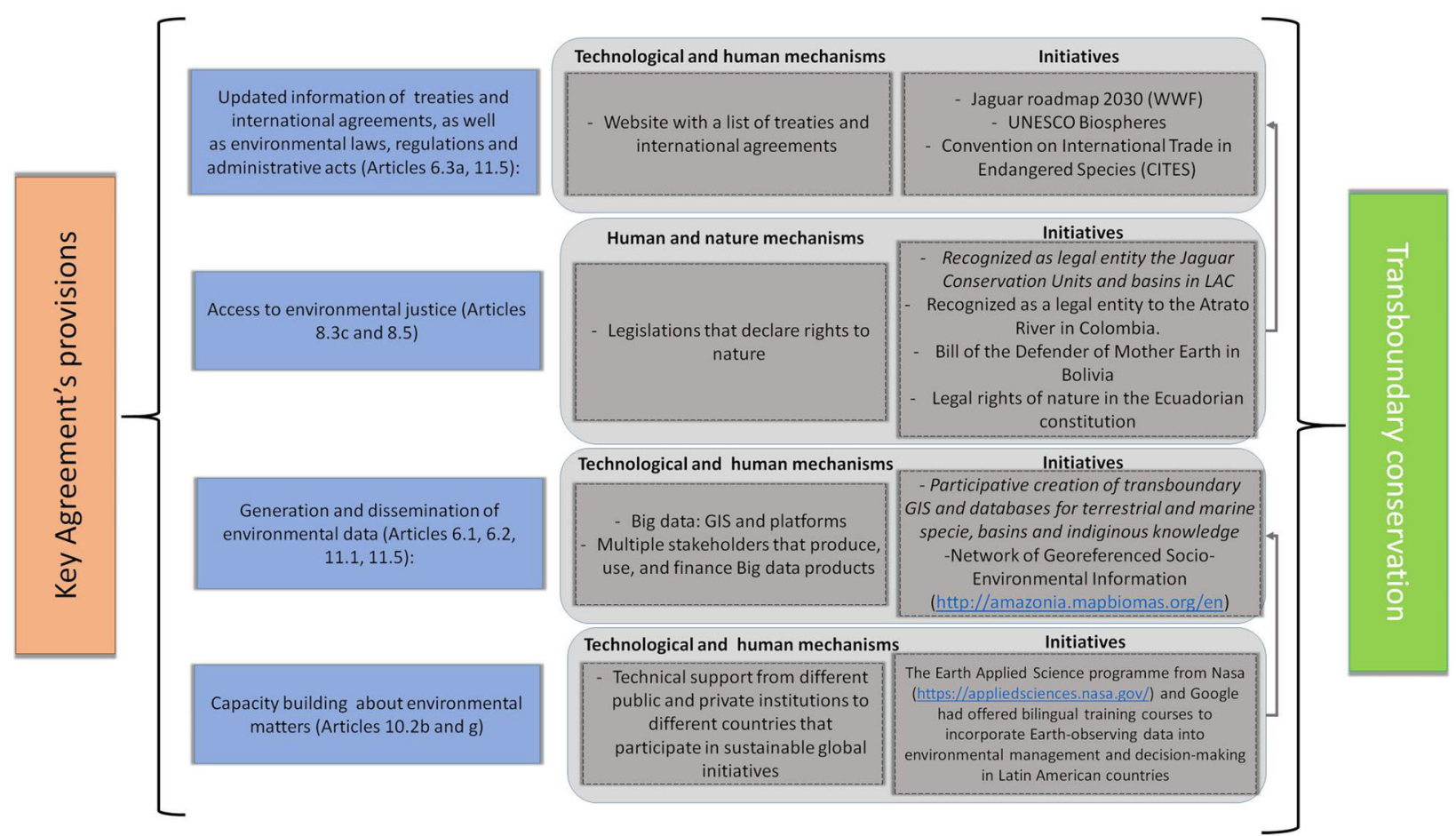

F I G U R E 3 Key Agreement provisions to foster transboundary conservation in LAC. The mechanisms and initiatives can interact. For instance, capacity building interacts with the generation and dissemination of environmental data. We proposed new initiatives (written in italics) and highlight key existing initiatives

habitats). In this case, human and technological mechanisms were integrated, with universities, local government authorities, and NGOs collaborating for the coproduction of the GIS framework.

Legislation also plays an important role for the protection of natural resources and biodiversity. Bolivia has a bill named "Bill of the Defender of Mother Earth," which provides a legal framework for institutions to penalize the destruction of nature and facilitates citizens to take legal action (Cano Pecharroman, 2018). Similar actions could be implemented at a transboundary scale, by giving legal entity recognition to the forest patches that are identified important for wide-ranging species, such the jaguar (Panthera onca) or to the transboundary basins. For instance, 14 LAC countries partnered to create a roadmap for 2030 to improve jaguars' habitats (WCS, 2018). Another important initiative to support is giving continuity to the trinational programme called "Putumayo Tres Fronteras” for protection of Putumayo's river basin between Ecuador, Peru, and Colombia (Cisneros \& Solórzano, 2017). In addition, the Agreement can learn from other international and transboundary initiatives that have been previously been and implemented in other regions (Table S3). For instance, omitting local stakeholder from the creation and implementation of conservation initiatives has neglect the views of key actors and hampered conservation success. Therefore, any transboundary initiatives stem- ming from the Agreement should consider integrating a bottom-up approach. Without implementing such enforceable provisions, transboundary conservation agreements risk becoming large-scale "paper parks" that have little or no formal management on the ground, or adversely affecting local communities.

\section{4 | CONCLUSIONS}

Our globalized world requires renewed international commitments to more effectively integrate environmental and human rights protection. It is, therefore, vital that the remaining countries sign and ratify the Agreement to foster environmental and human rights in the region and maximize conservation opportunities. We present mechanisms that show a pathway to enhance the Agreement's implementation. We highlighted different national initiatives that can be scaled-up into the LAC which have a direct relation to key provisions of the Agreement. More importantly, we found that many biodiverse countries with high levels of human right violations and sharing multiple ecosystems/species have not ratified the Agreement yet. Despite challenges associated with implementing initiatives at multiple scales (Fidelman et al., 2014), coordinated multilateral actions can have immense benefits for biodiversity conservation, decrease management costs 
in the long-run, and enhance existing collaborations and cogovernance mechanisms already in place (Mason et al., 2020). The legal binding nature of the Agreement that creates a connection between human rights and environmental matters can be used as a landmark for other international agreements in other regions for the recognition of human rights and nature conservation.

\section{ACKNOWLEDGMENTS}

SLC was supported by the doctoral fellowship award from COLCIENCIAS (No. 728) and the University of Queensland Research Training program. RKR was supported by an Australian Research Council Discovery Early Career Research Award (DE210100492). EGC is supported by a David H. Smith Conservation Research Fellowship. JRR was supported by an ARC Future Fellowship (FT200100096). Some figures were produced in autodraw.com from Creative Commons. We thank two anonymous reviewers for their comments on the manuscript.

\section{CONFLICT OF INTEREST}

The authors declare no conflict of interest.

\section{ETH ICS STATEMENT}

The manuscript does not contain field data. Our manuscript complies with ethical scientific standards.

\section{AUTHORS' CONTRIBUTIONS}

SLC and RKR led the manuscript conceptualization. AFSC and LAR provided the terrestrial, marine biodiversity, and basin data. AFSC and SLC produced the maps. SLC led the writing and all authors contributed with ideas and substantially edited the text.

\section{DATA AVAILABILITY STATEMENT}

We used the data developed by Manson et al. (2020) that were freely available in the University of Queensland eSpace repository (https://espace.library.uq.edu.au/view/ UQ:fd617fo).

\section{OR C I D}

Sofia López-Cubillos (1) https://orcid.org/0000-0002-98999099

Lina Muñoz-Ávila (1) https://orcid.org/0000-0001-63489825

Leslie A. Roberson (1) https://orcid.org/0000-0002-74900795

Andrés F. Suárez-Castro (iD https://orcid.org/0000-00026621-3821

Jose Manuel Ochoa-Quintero @ https://orcid.org/00000002-5619-0777

Renato Crouzeilles (10 https://orcid.org/0000-0002-88874751
Eduardo Gallo-Cajiao (1) https://orcid.org/0000-0002-

8607-2675

Jonathan Rhodes (1) https://orcid.org/0000-0001-6746-7412 Wolfram Dressler (1) https://orcid.org/0000-0003-1105-

3805

María José Martinez-Harms (1) https://orcid.org/0000-

0003-2655-3116

Rebecca K. Runting (10 https://orcid.org/0000-0003-06141456

\section{REFERENCES}

Amano, T., Sandel, B., Eager, H. Bulteau, E., Svenning, J. C., Dalsgaard, B., Rahbek, C., Davies, R. G., \& Sutherland, W. J. (2014). Global distribution and drivers of language extinction risk. Proceedings of the Royal Biological Society, 281, 20141574.

Anderson, E. P., Jenkins, C. N., Heilpern, S., Maldonado-Ocampo, J. A., Carvajal-Vallejos, F. M., Encalada, A. C., Rivadeneira, J. F., Hidalgo, M., Cañas, C. M., Ortega, H., Salcedo, N., Maldonado, M., \& Tedesco, P. A. (2018). Fragmentation of Andes-to-Amazon connectivity by hydropower dams. Science Advances, 4, eaao1642.

Armitage, D., De Loë, R., \& Plummer, R. (2012). Environmental governance and its implications for conservation practice. Conservation Letters, 5, 245-255.

Baldwin, K., \& Oxenford, H. A. (2014). A participatory approach to marine habitat mapping in the Grenadine Islands. Coastal Management, 42, 36-58.

Brown, G., \& Kyttä, M. (2018). Key issues and priorities in participatory mapping: Toward integration or increased specialization? Applied Geography, 95, 1-8.

Butt, N., Lambrick, F., Menton, M., \& Renwick, A. (2019). The supply chain of violence. Nature Sustainability, 2, 742-747.

Cano Pecharroman, L. (2018). Rights of nature: Rivers that can stand in court. Resources, 7, 1-14.

CEPAL. (2018). Acuerdo Regional sobre el Acceso a la Información, la Participación Pública y el Acceso a la Justicia en Asuntos Ambientales en América Latina y el Caribe. Santiago de Chile: Naciones Unidas (UN).

Cisneros, M., \& Solórzano, J. (2017). Comunidades locales y pueblos indígenas. Su rol en la conservación, mantenimiento y creación de áreas protegidas. Iniciativa Visión Amazónica. REDPARQUES, WWF, FAO, UICN, ONU Medio Ambiente.

Costello, M. J., Appeltans, W., Bailly, N., Berendsohn, W. G., De Jong, Y., Edwards, M., Froese, R., Huettmann, F., Los, W., Mees, J., Segers, H., \& Bisby, F. A. (2014). Strategies for the sustainability of online open-access biodiversity databases. Biological Conservation, 173, 155-165.

Coumans, C. (2019). Minding the "governance gaps": Re-thinking conceptualizations of host state "weak governance" and refocussing on home state governance to prevent and remedy harm by multinational mining companies and their subsidiaries. Extractive Industries and Society, 6, 675-687.

Crabbe, M. J. C., Martinez, E., Garcia, C., Chub, J., Castro, L., \& Guy, J. (2009). Is capacity building important in policy development for sustainability? A case study using action plans for sustainable marine protected areas in Belize. Society \& Natural Resources, 23, 181-190.

de la Fuente, A., \& Guzmán, S. (2016). México. In I. Calle \& D. Ryan, La participación ciudadana en los procesos de Evaluación de 
Impacto Ambiental. Análisis de casos en 6 países de Latinoamérica. (pp. 138-165). Lima, Perú: Sociedad Peruana de Derecho Ambiental.

Fidelman, P., Evans, L. S., Foale, S., Weible, C., von Heland, F., \& Elgin, D. (2014). Coalition cohesion for regional marine governance: A stakeholder analysis of the Coral Triangle Initiative. Ocean \& Coastal Management, 95, 117-128.

Frainer, A., Mustonen, T., Hugu, S. Andreeva, T., Arttijeff, E. M., Arttijeff, I. S., Brizoela, F., Coelho-de-Souza, G., Printes, R. B., Prokhorova, E., Sambou, S., Scherer, A., Shadrin, V., \& Pecl, G. (2020). Opinion: Cultural and linguistic diversities are underappreciated pillars of biodiversity. Proceedings of the National Academy of Sciences of the United States of America 117, 2653926543.

Garcia, L. C., Ribeiro, D. B., De Oliveira Roque, F., Ochoa-Quintero, J. M., \& Laurance, W. F. (2017). Brazil's worst mining disaster: Corporations must be compelled to pay the actual environmental costs. Ecological Applications, 27, 5-9.

Garnett, S. T., Burgess, N. D., Fa, J. E., Fernández-Llamazares, Á., Molnár, Z., Robinson, C. J., Watson, J. E. M., Zander, K. K., Austin, B., Brondizio, E. S., Collier, N. F., Duncan, T., Ellis, E., Geyle, H., Jackson, M. V., Jonas, H., Malmer, P., Mcgowan, B., Sivongxay, A., \& Leiper, I. (2018). A spatial overview of the global importance of Indigenous lands for conservation. Nature Sustainability, 1, 369374.

Global Witness. (2020). Defender el mañana.

Hileman, J., Bastos, M. T. A., \& Lubell, M. (2018). Robustness and the paradox of bridging organizations: The exit problem in regional water governance networks in Central America. Society \& Natural Resources, 31, 683-697.

Hiriart-Bertrand, L., Silva, J. A., \& Gelcich, S. (2020). Challenges and opportunities of implementing the marine and coastal areas for indigenous peoples policy in Chile. Ocean \& Coastal Management, 193, 105233.

Marcovitch, J., \& Pinsky, V. C. (2014). Amazon Fund: Financing deforestation avoidance. Revista de Administração, 49, 280-290.

Mason, N., Ward, M., Watson, J. E. M., Venter, O., \& Runting, R. K. (2020). Global opportunities and challenges for transboundary conservation. Nature Ecology \& Evolution, 4, 694-701.

OHCHR. (2011). Principios Rectores Sobre las Empresas y los Derechos Humanos. Office of the High Commissioner for Human Rights.

Oksanen, M., \& Kumpula, A. (2013). Transparency in conservation: Rare species, secret files, and democracy. Environmental Politics, 22, 975-991.

Prieur, M., Sozzo, G., \& Nápoli, A. (2020). Acuerdo de Escazú: Hacia la democracia ambiental en América Latina y el Caribe. Universidad Nacional del Litoral.

Prist, P. R., Levin, N., Metzger, J. P. de Mello, K., de Paula Costa, M. D., Castagnino, R., Cortes-Ramirez, J., Lin, D. L., Butt, N., Lloyd, T. J., López-Cubillos, S., Mayfield, H. J., Negret, P. J., Oliveira-Bevan, I., Reside, A. E., Rhodes, J. R., Simmons, B. A., Suárez-Castro, A. F., \& Kark, S. (2019). Collaboration across boundaries in the Amazon. Science (American Association for the Advancement of Science), 366, 699-700.

Rajão, R., \& Jarke, J. (2018). The materiality of data transparency and the (re)configuration of environmental activism in the Brazilian Amazon. Social Movement Studies, 17, 318-332.

Tierra de, R. (2021). Lo que dicen los datos sobre los ataques a los resistentes.
Rodríguez-Jorquera, I. A., Siroski, P., Espejo, W., Nimptsch, J., Choueri, P. G., Choueri, R. B., Moraga, C. A., Mora, M., \& Toor, G. S. (2017). Latin American protected areas: Protected from chemical pollution? Integrated Environmental Assessment and Management, 13, 360-370.

Rodríguez Garavito, C., \& Baquero Díaz, C. A. (2020). Conflictos socioambientales en América Latina: El derecho, los pueblos indígenas y la lucha contra el extractivismo y la crisis climática. Siglo XXI Editores.

Runting, R. K., Phinn, S., Xie, Z., Venter, O., \& Watson, J. E. M. (2020). Opportunities for big data in conservation and sustainability. Nature Communications, 11, 1-4.

Salaman, P., Cortés, A., \& Waugh, D. (2019). Back from the brink of extinction: How the recovery of the Yellow-eared Parrot united a nation. Conservación Colombiana, 26, 21-35.

Seele, P. (2017). Predictive sustainability control: A review assessing the potential to transfer big data driven 'predictive policing' to corporate sustainability management. Journal of Cleaner Production, 153, 673-686.

Shiel, C., Leal Filho, W., Do Paço, A., \& Brandli, L. (2016). Evaluating the engagement of universities in capacity building for sustainable development in local communities. Evaluation and Program Planning, 54, 123-134.

Stec, S., \& Jendrośka, J. (2019). The Escazú Agreement and the regional approach to Rio Principle 10: Process, innovation, and shortcomings. Journal of Environmental Law, 31, 533-545.

U.N. (2020). Colombia: El país latinoamericano con más asesinatos de defensores de derechos humanos, señala experto. United Nations News.

UNE. (2018). Who are environmental defenders?. UN Environment. United Countries Environment. United Nations Environmental Programme.

UNEP-WCMC. (2016). El estado de la biodiversidad en América Latina y el Caribe. Cambridge, Reino Unido: UNEP-WCMC.

Vásquez, J. P., \& Santafé, C. (2021). La historia del guardián de la selva del Guaviare. Voragine.

WCS. (2018). Latinoamérica lanza un nuevo plan para salvar al jaguar. Wildlife Conservation Society.

\section{SUPPORTING INFORMATION}

Additional supporting information may be found in the online version of the article at the publisher's website.

How to cite this article: López-Cubillos, S., Muñoz-Ávila, L., Roberson, L. A., Suárez-Castro, A. F., Ochoa-Quintero, J. M., Crouzeilles, R., Gallo-Cajiao, E., Rhodes, J., Dressler, W., Martinez-Harms, M. J., \& Runting, R. K. (2021). The landmark Escazú Agreement: An opportunity to integrate democracy, human rights, and transboundary conservation. Conservation Letters, e12838. https://doi.org/10.1111/conl.12838 


\section{University Library}

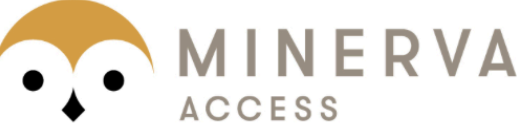

A gateway to Melbourne's research publications

Minerva Access is the Institutional Repository of The University of Melbourne

\section{Author/s:}

Lopez-Cubillos, S;Munoz-Avila, L;Roberson, LA;Suarez-Castro, AF;Ochoa-Quintero, JM;Crouzeilles, R;Gallo-Cajiao, E;Rhodes, J;Dressler, W;Martinez-Harms, MJ;Runting, RK

Title:

The landmark Escazu Agreement: An opportunity to integrate democracy, human rights, and transboundary conservation

Date:

2021-09-10

\section{Citation:}

Lopez-Cubillos, S., Munoz-Avila, L., Roberson, L. A., Suarez-Castro, A. F., Ochoa-Quintero, J. M., Crouzeilles, R., Gallo-Cajiao, E., Rhodes, J., Dressler, W., Martinez-Harms, M. J. \& Runting, R. K. (2021). The landmark Escazu Agreement: An opportunity to integrate democracy, human rights, and transboundary conservation. CONSERVATION LETTERS, 15 (1), https://doi.org/10.1111/conl.12838.

Persistent Link:

http://hdl.handle.net/11343/289738

License:

CC BY 